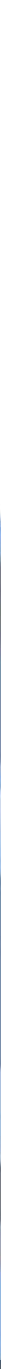

$9^{\circ}$ C O N G R E S O 2. CENTROAMERICANO DE H IS TO R I A

\title{
La Independencia en la historiografía didáctica
} nicaragüense

\section{Universidad de Costa Rica}

ISSN 1409-469X

Fecha de recepción: 15 de mayo 2008 Fecha de aceptación: 30 de mayo 2008

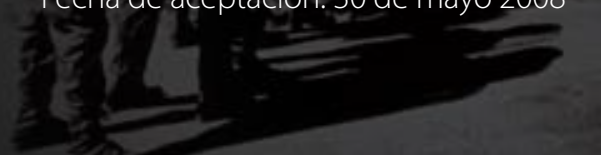

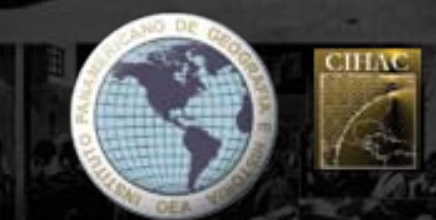

Editores Técnicos:

Allan Fonseca, Andrés Cruz, Gabriela Soto

Miembros del Consejo Editorial:

Dr. Ronny Viales, Dr. Juan José Marín

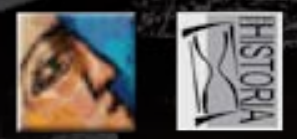


Indexaciones: Repositorio de Revistas UCR, DIALNET, Latindex, REDALYC Directorio y recolector de recursos digitales del Ministerio de Cultura de España, Directory of Open Access Journals. Diálogos Revista Electrónica de Historia ISSN 1409-469X. Número especial 2008. Dirección web: http://historia.fcs.ucr.ac.cr/dialogos.htm

\section{La Independencia en la historiografía didáctica nicaragüense}

Frances Kinloch Tijerino

Instituto de Historia de

Nicaragua y Centroamérica Universidad Centroamericana

Rotonda Rubén Darío 150

metros oeste

Managua, Nicaragua

Teléfonos: (505) 2787324

Correo electrónico:

franceskinloch@gmail.com 


\section{Introducción histórica}

Durante las primeras décadas de vida independiente, la idea de que los nicaragüenses constituían una colectividad política con un origen y un pasado común era muy débil. Las lealtades localistas, étnicas y religiosas obstaculizaban la consolidación de un poder central estable capaz de difundir un sentido de identidad nacional. La rivalidad entre las élites de las ciudades principales, aunada a los conflictos entre monárquicos y republicanos, unionistas y federalistas, liberales y conservadores, desencadenó una sucesión de guerras civiles que abrió las puertas a la ocupación del país por filibusteros estadounidenses en 1856-1857.

La grave amenaza externa obligó a las élites a unir esfuerzos para expulsar al invasor y, en 1858, se conformó una Asamblea Constituyente encargada de redactar una nueva Carta Magna acorde al carácter del pueblo nicaragüense, para dar inicio a la reconstrucción del país. El discurso pronunciado por el presidente del cuerpo legislativo en el acto de promulgación de la ley fundamental de la república revela la incertidumbre y el temor de los diputados, apremiados por la responsabilidad de definir a la comunidad nacional. Durante las sesiones, éstos se interrogaban:

"Debíamos ir a buscar los elementos de nuestra Constitución a la Metrópoli a donde pertenecimos como colonos? (...) Anudaremos nuestra legislación con nuestra sociedad aborigen? Las asociaciones a que podiamos pertenecer han desparecido, o más bien nosotros no reconocemos origen ninguno porque somos una mezcla heterogénea de raza indígena, africana y europea, y no tenemos con exactitud un punto fijo de partida (...). El tiempo será el único juez de nuestros errores o de nuestros aciertos. "1

Pese a sus temores, la élite logró construir cierto consenso en torno a los medios para fortalecer la autoridad central y preservar la paz. Conforme a las ideas de la corriente del liberalismo doctrinario o tradicionalismo - surgida en Europa en reacción a los excesos de la Revolución Francesa - la nueva Constitución limitó los derechos políticos a lo interno de un reducido círculo de grandes propietarios, estableciendo un sistema electoral indirecto así como requisitos económicos para votar y ocupar cargos públicos.

Al mismo tiempo, se estrechó la alianza entre el Estado y la Iglesia Católica. La práctica del catolicismo pasó a ser condición para optar a empleos gubernamentales, y se suprimió el derecho a ejercer otras religiones en público, contemplado en el Art. 53 de la anterior Carta Magna. ${ }^{2}$ 
La Constitución de 1858 permaneció vigente durante un período de relativa estabilidad conocido como los “Treinta Años Conservadores”, durante los cuales el Estado nicaragüense comenzó a impulsar un conjunto de políticas dirigidas a fomentar la agroexportación, construir la infraestructura necesaria para el desarrollo de las comunicaciones y modernizar el país.

En este contexto, la élite gobernante también empezó a sentar las bases culturales para la difusión de una identidad nacional homogénea, mediante la organización de rituales patrióticos para celebrar la independencia de España y la derrota de los filibusteros estadounidenses, la creación del sistema de educación pública, la apertura de los primeros institutos nacionales de enseñanza secundaria y la introducción de la asignatura de Historia de Nicaragua. ${ }^{3}$

En efecto, en 1877 se estableció la instrucción pública, gratuita y obligatoria para niños y niñas de 5 a 14 años, y se introdujo por primera vez en los planes de estudio la historia "profana”, a modo de complemento de la tradicional Historia Sagrada. En la misma década, por iniciativa de juntas de padres de familia, se crearon varios centros de educación secundaria que, si bien constituían empresas privadas, se hallaban bajo la supervisión de Academias Científicas integradas por funcionarios gubernamentales.

En la década de 1880 abrieron sus puertas dos Institutos Nacionales de educación media en Granada y León, bajo control directo del Poder Ejecutivo a través del Ministerio de Educación Pública, que se encargaba de nombrar a los profesores. ${ }^{4}$ En un inicio, los planes de estudio sólo incluían las asignaturas de Historia Universal e Historia de América; sin embargo, el Estado se preocupó por impulsar la enseñanza de la Historia de Nicaragua mediante el patrocinio de la investigación archivística y la convocatoria a un concurso oficial de libros de texto para impartir esta asignatura.

Aunque pertenecientes al Partido Conservador, los gobernantes de la década de 1880 - Joaquín Zavala, Adán Cárdenas y Evaristo Carazo - se mostraban tolerantes frente a la creciente difusión de la filosofía positivista a través de diversos periódicos y asociaciones literarias o políticas. Para entonces, los liberales habían llegado al poder en los demás países centroamericanos y, siguiendo el espíritu de los tiempos, los mandatarios nicaragüenses se preciaban de "progresistas”. Esta apertura ideológica permitió que, entre 1882 y 1889, el Estado auspiciara la publicación de dos obras monumentales de Historia de Nicaragua: una claramente marcada por el tradicionalismo y la otra por las ideas de Auguste Comte.

La primera, escrita por Tomás Ayón, consta de tres tomos editados sucesivamente en 
1882, 1887 y 1889, que abarcan en sus 1,293 páginas la historia de Nicaragua desde el período precolombino hasta la independencia. Conforme a su ideología tradicionalista, Ayón justifica la ruptura colonial como punto de partida del nuevo Estado soberano pero, a la vez, reivindica el legado cultural español como base de la identidad nacional.

En contraste, José Dolores Gámez - autor de la segunda - rechaza de manera tajante la herencia de España y, sobre todo, de la Iglesia Católica, proponiendo de manera implícita la idea de una nación moderna, secular y cosmopolita.

A partir de estas obras seminales, en el siglo XX se desarrollaron dos corrientes historiográficas opuestas, que se plasmaron en manuales claramente marcados ya sea por la ideología liberal o por la conservadora. Los primeros circulaban, sobre todo, en institutos nacionales o laicos, mientras los segundos eran de estudio obligatorio en los colegios religiosos privados.

De cierta manera, la coexistencia de estas dos versiones de la historia de Nicaragua era un reflejo del sistema político del país, dominado desde 1937 hasta 1979 por una dictadura militar de bandera liberal que se legitimaba, de cara al exterior, mediante farsas electorales celebradas en comparsa con el Partido Conservador.

En la década de 1980, la enseñanza de la Historia en Nicaragua experimentó un giro radical a raíz del triunfo de una masiva insurrección popular que, encabezada por el Frente Sandinista de Liberación Nacional (FSLN), puso fin a los 42 años de dictadura de la familia Somoza. Como resultado, irrumpió una visión del pasado que minimizaba la trascendencia de la proclamación de la independencia de España, y situaba el origen de la nueva nación revolucionaria en otra efeméride más significativa: el 19 de julio de 1979, día de la victoria sandinista.

A partir de 1990, después del triunfo electoral de una alianza libero-conservadora, la historiografía didáctica se debate entre los impulsos por desmantelar y reestructurar las imágenes del pasado con fines políticos, y los esfuerzos por profesionalizar esta disciplina y dar a la enseñanza de la historia su auténtica función: desarrollar la capacidad de pensamiento crítico de los futuros ciudadanos del país.

En este artículo nos proponemos examinar el desarrollo y los vaivenes de la historiografía didáctica nicaragüense desde fines del siglo XIX hasta el presente, teniendo como hilo conductor el análisis del tratamiento de dos conjuntos temáticos estrechamente vinculados entre sí: la valoración de las culturas aborígenes y del legado colonial, así como la interpretación de las causas y consecuencias de la Independencia. 


\section{Las obras seminales}

\subsection{El mundo aborigen y el legado colonial}

A través de su obra de Historia de Nicaragua, Tomás Ayón contribuyó a crear un elemento fundamental del imaginario nacional: la idea de que los nicaragüenses constituían una colectividad con un pasado común "desde los tiempos más remotos". ${ }^{5}$ A la vez, su valoración de las culturas aborígenes e interpretación del legado colonial proporcionaron un basamento histórico a los esfuerzos del Estado por construir una nación racial y culturalmente homogénea, promoviendo un sentido de identidad en torno al concepto del mestizaje.

Resulta evidente, sin embargo, que la idea de homogeneidad no era sinónimo de igualdad; por el contrario, la visión de la identidad mestiza se basaba en la premisa de la inferioridad de la cultura indígena con respecto a la hispánica, y en la oposición entre barbarie y civilización.

La obra de Ayón se halla estructurada en tres tomos, el primero de los cuales abarca desde el período precolombino hasta el año 1600. Sin embargo, tan sólo 29 de sus 358 páginas se ocupan de los antiguos habitantes del actual territorio nicaragüense antes de su "descubrimiento", y en ellas abundan los estereotipos racistas cuando contrasta los pueblos primitivos americanos con las civilizadas naciones europeas. ${ }^{6}$

La posición ideológica de Ayón es muy notoria en sus juicios sobre la religión de los pueblos indígenas: éstos prestaban adoración supersticiosa a falsas deidades a quienes - "en la espantosa oscuridad de su barbarie" - ofrecían sacrificios humanos; además, tenían "nociones imperfectas sobre el verdadero bien y el verdadero mal".7

Aunque a continuación el autor denuncia la crueldad de los conquistadores y los vicios del régimen colonial, se cuida de salvar de toda responsabilidad a los Reyes Católicos, e insiste en la superioridad de la civilización española:

"Hacer luz en las tinieblas en que se hallaba la raza americana; traer la civilización a su barbarie; cambiar su idolatría en elevados sentimientos morales; modificar sus costumbres selváticas, enseñándole la vida de los pueblos civilizados: esa debió ser la acción benéfica de la conquista, esa la gloria positiva de la nación conquistadora, si los capitanes que tomaban posesión del Nuevo Mundo hubieran cumplido con puntualidad las disposiciones de los soberanos de Castilla". ${ }^{\circ}$

Además, Ayón considera preciso reconocer que la introducción del "elemento europeo" trajo considerables beneficios para las generaciones formadas del "cruzamiento de las razas", y valora la conquista como el origen de la nación mestiza: 
"No nos proponemos enumerar todos los beneficios que produjo la conquista: baste decir que ella constituye la base de la actual civilización hispano-americana, y que preparó a estos países un destino mejor, porque cambiando la condición de sus habitantes, les hizo conocer los derechos del hombre en sociedades organizadas, y más tarde, cuando ellos recobraron su independencia, pudieron tomar el cuidado de conducirse por si mismos y procurar su felicidad, como lo practican las naciones libres". 9

No obstante - aclara Ayón - estos beneficios no fueron extensivos a la raza indígena. Aunque por la "suavidad de su carácter", laboriosidad e inteligencia natural, éstos se hallaban predispuestos a civilizarse, permanecieron en su "primitiva oscuridad" sepultados en las minas de oro y plata, desnudos y hambrientos en medio de la abundancia, aplastados por el yugo del trabajo forzoso y el látigo de los encomenderos. ${ }^{10}$

En 1889, irrumpió una visión distinta de la nación nicaragüense construida a partir de las premisas del positivismo y de “un criterio democrático liberal”, según palabras de su autor José Dolores Gámez. Su obra titulada Historia de Nicaragua, desde los tiempos prehistóricos hasta 1860, en sus relaciones con España, México y Centro América, fue premiada en un concurso oficial y declarada de texto para los establecimientos nacionales de Nicaragua. ${ }^{11}$

Bajo la influencia del positivismo, Gámez anhelaba una nación moderna, cosmopolita y secular, libre de las ataduras de las tradiciones e instituciones españolas. Por tanto, rechaza la idea de que la obra de la Corona y, sobre todo, de la Iglesia Católica, pudiera haber traído algún beneficio a los pueblos americanos.

A diferencia de Ayón, Gámez sostiene que los conquistadores españoles encontraron en Centroamérica una civilización bastante adelantada para aquella época, pero sus vestigios fueron destruidos por el fanatismo del clero: "La historia del país se mantenía archivada, y personas especialmente encargadas de ella, escribían grandes libros, que se conservaban con cuidado. Desgraciadamente el celo religioso de los misioneros españoles, según dice el padre Las Casas, dio fin con todos ellos, arrojándolos al fuego como tradiciones del demonio". ${ }^{12}$

Las leyes civiles y penales de los aborígenes - afirma Gámez - eran, en más de un aspecto, superiores a las que regían en España en el siglo XVI, donde predominaban la educación del cuartel y las intolerantes doctrinas de la Inquisición. Además, describe a los conquistadores como la "escoria de la sociedad española": hordas aventureras motivadas por una codicia desenfrenada que convirtieron a América en perpetuo botín de guerra por espacio de 300 años. ${ }^{13}$

Antes de abordar el tema de la independencia, Gámez hace un alto en su narrativa para dirigir una mirada retrospectiva sobre el período colonial en su conjunto. Entre sus aspectos más negativos destaca los estancos reales y las restricciones al comercio, los tributos, impuestos y 
contribuciones arbitrarias exigidas por autoridades locales y la Iglesia Católica, de manera que al finalizar el siglo XVIII "solamente el clero podia hacer alarde de prosperidad".

Asimismo, critica el sistema administrativo colonial que establecía la supremacía de los peninsulares, creando abismos de odio en la sociedad, así como el sistema jurídico con sus penas de muerte, azotes, tormentos e imaginarios delitos contra la divinidad. Sobre todo, lanza sus dardos contra el papel de la Iglesia Católica como sostén ideológico del sistema colonial:

"El clero, que era el árbitro de la enseñanza y el brazo fuerte del poder civil, se apropiaba del niño desde su nacimiento, le inculcaba las ideas que más convenían á su objeto, y perseguía al hombre en todas sus edades, sin despedirse de él, ni aún al borde del sepulcro. Así se explica que explotaba la credulidad pública con tanto aplomo, en provecho propio y en el del Rey a quien servía”. ${ }^{4}$

Cuatro años después de la publicación de esta obra, se produjo el triunfo de la Revolución Liberal en Nicaragua, encabezada por el presidente José Santos Zelaya, quien gobernó el país hasta 1909. Gámez pasó a ser uno de sus principales ideólogos y llegó a ocupar el cargo de Ministro de Educación. Su interpretación sobre el pasado colonial contribuyó a justificar los decretos estatales dirigidos a privatizar las tierras de la Iglesia Católica con el fin de ponerlas a disposición de empresarios agroexportadores. Además, se prohibió la enseñanza de la religión en las escuelas del país, las fiestas populares de patrones titulares, las procesiones religiosas, el uso del traje talar y el cobro por la administración de los sacramentos, a la vez que se estableció el matrimonio civil y los cementerios laicos. ${ }^{15}$

\subsection{La Independencia y sus consecuencias}

\subsubsection{Causas}

Ayón y Gámez coinciden en explicar el proceso independentista centroamericano desde una perspectiva amplia, situándolo en el contexto de la difusión de las ideas de la Revolución Francesa, el ejemplo de la independencia de Estados Unidos, la crisis de la monarquía española provocada por la invasión napoleónica, y el inicio de la "revolución hispano-americana" en América del Sur.

Entre estos factores, destacan el impacto de la usurpación del trono por Bonaparte que, a juicio deAyón, "suspendió de hecho la autoridad del Monarca español y arrebató a España su personalidad de nación”, abriendo a los hispanoamericanos la oportunidad de romper el duro yugo que los había oprimido durante tres siglos. Las tardías concesiones ofrecidas por las Cortes de Cádiz más bien acrecentaron sus aspiraciones independentistas. Y, según Gámez, la propaganda libertaria de los patriotas españoles que luchaban contra Bonaparte fue una espada de dos filos, pues los americanos se apropiaron de los mismos principios para enfrentar a la metrópoli. 
Asimismo, ambos autores enfatizan la importancia de la difusión de las ideas de la Revolución Francesa en las colonias, a través de libros infiltrados de contrabando que eran leídos con ansiedad. Estas ideas deslumbraron a los hispanoamericanos y crearon grandes expectativas en torno al republicanismo, percibido como un sistema más adecuado a la naturaleza de la sociedad humana que el absolutismo monárquico. ${ }^{16}$

\subsubsection{Primera etapa del proceso independentista}

Ambos autores identifican dos etapas en el proceso independentista. Ayón otorga especial importancia a los acontecimientos ocurridos en la provincia de Nicaragua entre 1811 y 1812. En un capítulo titulado: "Primeros movimientos de insurrección contra España”, insiste en su origen popular y espontáneo, destacando la beligerancia de los indígenas de Masaya y de los pobladores de los barrios de León y Rivas.

Al referirse a los sucesos de Granada, principal foco de la insurrección del año 1812, Ayón explica que si bien la mayoría de los miembros del Ayuntamiento eran partidarios de la independencia, su pretensión de dirigir el movimiento se vio desbordada por el pueblo, que "aspiraba á una transformación profunda y radical".

De acuerdo a la narrativa de Ayón, el 21 de abril más de 400 civiles voluntarios, apoyados por numerosos milicianos del batallón de Granada, se enfrentaron a las tropas enviadas por el Capitán General para aplastar la rebelión. "Sobresaltados y medrosos por el repentino vuelo que había tomado la insurrección", los miembros del Ayuntamiento negociaron una amnistía con el jefe de las tropas reales a cambio de poner fin "a las conmociones populares".

Posteriormente, dicho acuerdo fue violado por el Capitán General, quien condenó a muerte a 16 miembros de las principales familias de la ciudad y les confiscó sus bienes. Otras 180 personas fueron condenadas a prisión o destierro, entre éstas, los frailes Benito Miguelena y Benito Soto, y tres mujeres granadinas: Josefa Chamorro, María Gregoria Robleto y María Ulloa. ${ }^{17}$

Mientras Ayón dedica 36 páginas a describir en detalle las sublevaciones ocurridas en Nicaragua entre 18111812, Gámez les concede tan sólo 4, y ofrece una versión distinta en cuanto al papel de los actores sociales y sus aspiraciones. En efecto, atribuye la decisión de algunos miembros del Ayuntamiento de Granada de deponer a las autoridades coloniales a motivos meramente egoístas, rechazando de manera implícita la posibilidad de considerarlos como "próceres”. Según Gámez, los criollos "permanecían bien hallados con las ideas políticas y filosóficas de la colonia; pero herederos del orgullo y carácter preponderante de los conquistadores, no podían avenirse con vivir eternamente menospreciados y humillados por los peninsulares".

Además, Gámez atribuye el fracaso de este primer movimiento independentista a la falta de apoyo popular, explicando que el pueblo "no podía tomar interés por una causa que ni siquiera se imaginaba”, pues se hallaba dominado por una educación calculada para mantenerlo en perpetua servidumbre: "Mal podía secundar la causa de los independientes un pueblo acostumbrado a no oír otra voz que la del fanatismo, que alimentaba sus creencias con absurdos extravagantes, entretenía su curiosidad con falsos milagros y 
veía con horror todo lo que tendía a sacarlo de su abyección e ignorancia”.

De acuerdo a Gámez, la Iglesia Católica jugó un papel determinante en todo el Reino de Guatemala para frenar la participación popular en la lucha libertaria. En sus prédicas, el clero atribuía a los líderes independentistas la intención de acabar con la religión, convertir los templos en caballerizas, degollar a los sacerdotes, violar a las vírgenes y profanar los vasos sagrados del culto. "Para corroborar tan groseras calumnias se fingían milagros, se inventaban castigos del cielo, se fulminaban excomuniones y se empleaban otras mil supercherías, procurando siempre atraer sobre los patriotas la execración de los pueblos crédulos ". ${ }^{18}$

\subsubsection{Segunda etapa del proceso independentista}

Ayón y Gámez coinciden en destacar el restablecimiento de la Constitución de Cádiz como un momento clave en la culminación del proceso independentista. A mediados de 1820, cuando se conoció esta noticia en el Reino de Guatemala, se organizaron dos partidos políticos que difundían sus ideas a través de los periódicos El Editor Constitucional y El Amigo de la Patria, editados por el intelectual liberal Pedro Molina y el conservador José Cecilio del Valle, respectivamente. Pese a sus diferencias ideológicas, tanto Ayón como Gámez reconocen los méritos intelectuales de dichas personalidades y destacan su protagonismo en esta coyuntura.

Asimismo, ambos identifican la independencia de México como el antecedente inmediato de la emancipación de Centroamérica. Esta noticia llegó a oídos del Capitán General Gabino Gainza a inicios de septiembre de 1821, convenciéndolo de que, bajo tales circunstancias, sería imposible conservar el dominio colonial en el Reino de Guatemala

Por tanto, Gainza convocó a un cabildo abierto en el Palacio Gubernamental de la capital el 15 de septiembre, para tomar una decisión al respecto. Al referirse a esta trascendental reunión, Gámez coincide con Ayón en resaltar la presencia de una "inmensa y compacta muchedumbre" acaudillada por los liberales Molina y Barrundia, que desde las afueras del palacio ejerció una eficaz presión sobre los realistas.

Además, Gámez destaca en un tono heroico el protagonismo del "erudito nicaragüense don Miguel Larreinaga", atribuyéndole el mérito de haber combatido "con su palabra de fuego" la propuesta de postergar la declaración de la independencia que, en ese momento, hubiera significado la "muerte de la idea redentora". Por el contrario, Ayón se limita a incluir a Larreinaga en una lista con otras 23 personas que votaron a favor de la moción de proclamar la independencia de inmediato. ${ }^{19}$

El último tomo de la obra de Ayón cierra con la independencia, pero Gámez dedica casi la mitad de su texto a los sucesos ocurridos entre 1821 y 1858. Al explicar las causas de la crónica inestabilidad política del llamado "Período de la Anarquía”, el historiador liberal enfatiza las rivalidades entre las diversas regiones y ciudades de la provincia, las aspiraciones e intereses de los líderes, y "más que todo, el fanatismo religioso, que se explotó como nunca". 
Finalmente, Gámez otorga "el primer lugar entre los padres y fundadores de la patria” a José Cecilio del Valle y Miguel Larreinaga por su erudición, a Pedro Molina por su ardor patriótico, a Francisco Morazán por su talento militar en la defensa del unionismo centroamericano, a José Francisco Barrundia por sus "escritos de fuego" a favor de la causa republicana y al estadista liberal Dionisio Herrera, Jefe del Estado de Nicaragua entre 1829 y $1833 .{ }^{20}$

\section{Corrientes historiográficas en el Siglo XX}

\subsection{La escuela de Gámez}

Gámez difundió su visión histórica a través de diversas obras de síntesis concebidas para la enseñanza primaria, que redactó en su llamado estilo "socrático" de preguntas y respuestas cortas bajo los títulos de Catecismo de Historia Patria e Historia de Centroamérica. En 1907, siendo Ministro de Educación Pública, Gámez escribió el primer tomo de un Compendio de Historia de Centro América destinado a la enseñanza secundaria. ${ }^{21}$ Sin embargo, poco después rompió con Zelaya y, cuando los liberales cayeron del poder en 1909, se vio obligado a salir al exilio, lo que impidió la publicación del segundo tomo.

No obstante, la influencia de José Dolores Gámez sobre la historiografía didáctica posterior fue tan duradera que es posible identificar su "escuela" en diversos textos publicados desde fines del siglo XIX hasta la década de 1970.

María A. Gámez fue la discípula más cercana del fundador de la historiografía liberal nicaragüense. En 1896 publicó una síntesis de la obra de su padre adaptada para la enseñanza primaria bajo el título de Compendio de Historia de Nicaragua - fiel en su contenido aunque no en el estilo, criticado por las nuevas corrientes pedagógicas. En las décadas siguientes continuó actualizando dicho texto, que alcanzó su octava edición en 1936. ${ }^{22}$

Otro de sus discípulos fue Sofonías Salvatierra, autor de un Compendio de Historia de Centro América, para los Institutos y Escuelas Normales. La primera edición se publicó en 1943 y, en 1964 fue reeditado por quinta vez. Siguiendo en cierto modo la estructura del texto de Gámez, antes de abordar el tema de la independencia Salvatierra recapitula las consecuencias negativas del régimen colonial en la economía, la cultura y la sociedad de la provincia. En términos particularmente crudos, describe el supuesto proceso de deshumanización sufrido por los indígenas durante la Colonia, debido a los siglos de aislamiento, opresión y servidumbre:

"Vivían en los montes, en caseríos que llamaban pueblos de indios, bajo la jurisdicción moral de los padres curas. (...) El vestido usual que cubría a los indios era poco menos que 
el de Adán y Eva. De esta manera circulaban en pueblos, valles y caminos, medio cubiertas las mujeres en la cintura por un refajo. Este vestido incompleto, más pagano que cristiano, estimulaba lo que era muy común y constante entre los indios: la unión de los sexos en el mismo lugar donde se encontraban; y como era costumbre, ni se recataban ni lo tenían por vergonzoso. La embriaguez y el amancebamiento era lo normal entre los indios". ${ }^{23}$

En otro acápite de su libro, Salvatierra sostiene que, si bien la conquista interfirió con el desarrollo de la raza aborigen, la potencia de su sangre fructificó en el mestizo, a quien se deben los "grandes progresos alcanzados en la parte indo-española de América." ${ }^{24}$ En suma, Salvatierra idealiza el mestizaje como base de la identidad hispanoamericana; sin embargo, su discurso está estrechamente vinculado a la percepción del indio como una "raza degradada". Dicha interpretación sobre las consecuencias de la conquista en la población aborigen dio lugar a la construcción de un estereotipo peyorativo para encasillar no sólo a los indígenas de la época colonial sino también a sus descendientes.

La influencia de Gámez se observa también en el texto Apuntes de Historia de Nicaragua del profesor Ofsman Quintana Orozco, ampliamente utilizado en la educación media durante las décadas de 1960 y 1970. En términos generales, cuando valora el mundo indígena y el legado colonial, o interpreta las causas de la independencia y de los conflictos posteriores, Quintana se limita a parafrasear fragmentos de la obra del maestro decimonónico. Por ejemplo, si Gámez se refiere a los conquistadores como la "escoria de la sociedad española", Quintana los describe, en un lenguaje más popular, como "individuos de baja procedencia, reos embarcados con promesas de indultos, vagos, etc. ${ }^{25}$

Pese a su contenido simplista y deficiente redacción, el manual de Quintana era recomendado por el Ministerio de Educación Pública para la enseñanza de la Historia de Nicaragua en el Primer Año del Ciclo Básico y el II Año del Ciclo Diversificado. En consecuencia, gozó de amplia difusión en los institutos nacionales y privados, alcanzando su octava edición en 1977.

\subsection{El nacional catolicismo}

En reacción a la ocupación militar estadounidense que redujo a Nicaragua a un status neocolonial entre 1912 y 1932, y en el contexto general del auge del nacional catolicismo en España y América del Sur, surgió una 
nueva corriente en la historiográfica didáctica nicaragüense que reivindica con vehemencia la tradición hispánica y católica.

El principal artífice de este discurso, cuyos ecos perdurarán hasta la década de 1970, fue Luis Alberto Cabrales. En el prólogo de su texto de Historia de Nicaragua, publicado en 1935, Cabrales insta a los maestros a hacer "hincapié en la continuidad histórica de la lucha contra las naciones de distinta raza y cultura. Especialmente la lucha contra la raza y cultura anglosajona, lucha que es la vértebra principal de nuestra historia". ${ }^{26}$

Por otra parte, Cabrales ensalza la obra colonial, contrastando el mundo indígena con la España del siglo XVI. Mientras los “primitivos habitantes de Nicaragua” estaban divididos en tribus, hablaban varios dialectos y no dejaron grandes edificios, los españoles habían alcanzado "una gran perfección" en las artes y oficios, la agricultura y la ciencia. Hablaban una de las lenguas “más hermosas y ricas de la Europa y del mundo"; tenían imprentas, universidades, palacios y catedrales.

Por tanto, Cabrales llega a la conclusión de que la Conquista benefició a los indígenas: “En la realidad, había sido trasladada a América la organización española. Estos últimos (los indios) habían salido ganando: de las manos de los caciques crueles y antropófagos, pasaron a manos de otros, que si es verdad fueron crueles, sobre todo en los primeros tiempos, prohibian los sacrificios humanos, y los iniciaban en la civilización cristiana. "27

Al igual que Gámez, antes de abordar las causas de la independencia, Cabrales echa una ojeada general sobre el siglo XVIII pero, a diferencia del primero, sólo percibe progreso y prosperidad económica en las ciudades. Además, encuentra indicios de adelanto intelectual y conciencia ciudadana en mestizos e indios, como resultado de las leyes protectoras de los Reyes de España y de la instrucción impartida por párrocos y misioneros.

Por tanto, atribuye la ruptura colonial exclusivamente a la rivalidad entre criollos y peninsulares: "Los criollos -españoles nacidos en América- a medida que acrecentaron sus fortunas y que adquirieron una gran cultura, fueron cada vez más apegándose a la idea de que ellos, y no los peninsulares, debían gobernar, en nombre del Rey, estos países. Por derecho de conquista, decían, el gobierno pertenece a nosotros que somos descendientes de conquistadores". 28

Cabrales concede un espacio mínimo en su obra a los conflictos del período post independentista, atribuyéndolos tan sólo a las ambiciones personales y el odio. Ya en el prólogo 
había justificado esta decisión instando a los maestros a tener siempre presente que esta asignatura no debe enseñarse como ciencia, sino como una disciplina cívica y moral, formadora del patriotismo. Por tanto, les aconseja abstenerse de "recordar detalles de combates fratricidas, detalles que no tienen ninguna importancia histórica y que fomentan en los nicaragüenses la pasión partidista, de suyo antinacional ${ }^{29}$ Cabrales difundió esta interpretación del pasado a través de otras obras, como su Historia de Nicaragua para las escuelas primarias que salió a luz en 1993 y llegó a su octava edición en 1951. ${ }^{30}$

Una visión similar se halla en la Historia Universal de Centro América y Nicaragua publicada por los Hermanos de las Escuelas Cristianas, que alcanzó su decimosegunda edición a mediados de la década de 1960. En este último libro, la valoración del mundo indígena es particularmente negativa. Se afirma que todos los pueblos descubiertos y conquistados por España, salvo México y Perú, "estaban sumidos en la mayor barbarie". Por otra parte, se asegura que la Religión Católica fue el principal instrumento empleado para colonizar América y civilizar a los indígenas, por lo cual los reyes de España "jamás toleraron que se implantase la esclavitud".

De acuerdo a los autores, la principal causa interna de la independencia fue la rivalidad entre criollos y peninsulares, así como "el espíritu de imitación" pues Guatemala se separó de España para no quedar en zaga al resto de América. Y, entre las causas externas, a la par del ejemplo de los Estados Unidos y la invasión napoleónica, incluye: “La intromisión del filosofismo ateo y masónico en España, que culminó con la expulsión de los jesuitas de la península y de sus dominios".

Siguiendo dicha lógica, los autores de este manual atribuyen a un sacerdote la iniciativa de demandar la ruptura con la península en el cabildo abierto del 15 de septiembre de 1821: "Entonces se levantó el canónigo José María Castilla y dijo que ya había llegado el momento de proclamar la Independencia. Todo el pueblo colmó de aplausos su discurso, y acto seguido se proclamó la Independencia." ${ }^{31}$

Dentro de esta corriente también se ubica la Historia de Nicaragua de Ricardo Páiz Castillo, que alcanzó su sexta edición en 1976. Aunque denuncia las crueldades de los conquistadores, el autor afirma que una vez "pasada la etapa de la conquista y en plena colonización española, correspondió a los misioneros la grandiosa empresa de civilizar y cristianizar a la raza dominada”. 
Con respecto a las causas de la independencia, Páiz Castillo atribuye gran importancia a los defectos personales de las autoridades coloniales en Guatemala. Por ejemplo, señala que el carácter violento, despótico y cruel del Capitán General José Bustamante y Guerra “alejó cada vez más las voluntades y simpatías generales de la Madre Patria”. Después, el “carácter voluble y acomodaticio” de su sucesor, General Gabino Gainza, alentó las esperanzas de los patriotas de alcanzar la emancipación "sin obstáculos insuperables por parte de las autoridades superiores". En esta misma línea, asegura que las guerras del período post independentista obedecieron tan sólo a "las ambiciones de hombres inescrupulosos y llenos de odios entre sí. ${ }^{32}$

\subsection{La historiografía sandinista}

En 1979 la enseñanza de la Historia en Nicaragua experimentó un giro radical como resultado del triunfo de una masiva insurrección popular que, encabezada por el Frente Sandinista de Liberación Nacional (FSLN), puso fin a los 42 años de dictadura de la familia Somoza. El Ministerio de Educación elaboró nuevos programas y guías metodológicas para orientar a los profesores en la preparación de sus planes de clase, pero en los diez años de gobierno sandinista no se publicaron libros de texto específicos para la enseñanza de esta asignatura en la educación media.

Sin embargo, los profesores contaban con una obra de referencia de obligada consulta: los Apuntes de Historia de Nicaragua publicados en 1980 por la Universidad Nacional. El primer tomo de esa obra abarca desde el siglo XIX hasta mediados de la década de 1950, pero concede tan sólo una y media de sus 193 páginas al tema de la independencia. En contraste, dedica el 43\% de su contenido a un tema prohibido bajo la dictadura somocista: la lucha que durante seis años libró el líder nacionalista Augusto C. Sandino en contra de los Marines. El segundo tomo, con una extensión de 425 páginas, consiste de una selección de textos de dirigentes sandinistas que abordan el surgimiento, desarrollo y triunfo del FSLN entre 1956 y 1979.

Con respecto al tema que nos ocupa, de acuerdo a este texto los primeros brotes de “rebelión independentista” que estallaron en 1811 en El Salvador, Nicaragua y Honduras, fueron "movimientos urbanos dirigidos no por las masas oprimidas de las Provincias contra sus minorías dominantes, sino más bien por estas últimas contra las autoridades coloniales”. Sin embargo, a continuación aclara que las minorías dominantes provinciales buscaron independizarse "no sólo 
de España, sino que principalmente de la oligarquía comercial guatemalteca" que monopolizaba las exportaciones e importaciones en toda la región.

En 1821, la aristocracia guatemalteca logró anticiparse a una posible toma del poder político por parte de las minorías dominantes de las provincias, mediante una alianza con las autoridades de la capital del reino para proclamar la independencia de forma pacífica. El éxito de dicho plan significó que la ruptura colonial no se diera para transformar el status quo sino para perpetuarlo, es decir, para mantener invariable la estructura económica. ${ }^{33}$

La desvalorización de la efeméride del 15 de septiembre de 1821 contrasta con el significado trascendental que se atribuye, en el segundo tomo del texto, al 19 de Julio de 1979: el momento culminante de toda una lucha popular iniciada con la resistencia indígena frente a los conquistadores. Esta visión teleológica de la historia sugiere que el origen de la nueva nación nicaragüense no radica en la independencia de España, sino en el triunfo irreversible del FSLN sobre la dictadura de medio siglo impuesta por el imperialismo norteamericano. ${ }^{34}$

No obstante, en la segunda mitad de la década de 1980, la emancipación de España cobró importancia en los documentos distribuidos por el Ministerio de Educación a los profesores de educación media. Por ejemplo, el programa de Historia Moderna y de América se proponía lograr que los alumnos valoraran la participación de las masas populares en la guerra independentista, así como el protagonismo de Bolívar, Sucre, Hidalgo, Morelos y Martí y otros luchadores de las causas justas como ejemplo de sacrificio y patriotismo.

En el ámbito de los objetivos actitudinales, el programa proponía “continuar desarrollando en los alumnos sentimientos de solidaridad, internacionalismo, nacionalismo y antiimperialismo al estudiar las luchas independentistas en América y toda nueva forma de explotación a fin de lograr una mayor identificación con los pueblos que luchan por su liberación”. Además, "que los alumnos comprendan la necesidad de incorporarse a la defensa de la patria ante las continuadas pretensiones de dominación Norteamericanas". ${ }^{35}$

Cabe recordar que durante esos años el presidente estadounidense Ronald Reagan se hallaba empeñado en derrocar al gobierno sandinista, proporcionando recursos y armamento a los sectores que se le oponían. Como resultado de una serie de errores del FSLN, en sus políticas hacia el campesinado y las etnias de la Costa Atlántica, en 1984 la "Contra” contaba ya con unos 15 mil combatientes y, en 1987, se había convertido en un ejército de unos 25 mil soldados. La cruenta guerra incidía en todos los aspectos de la vida del país. 
En este contexto, la Universidad Nacional publicó una nueva edición del libro Apuntes de Historia de Nicaragua, que si bien conserva la intención de desvalorizar la efeméride del 15 de septiembre de 1821, hace énfasis en la participación de las masas populares durante todo el proceso de emancipación colonial. En efecto, el texto destaca las “raíces populares" de los primeros levantamientos anticolonialistas, afirmando que en 1811 y 1812 "el pueblo movilizado en armas exigió la destitución de las autoridades españolas”.

Asimismo, se afirma que, a diferencia de Suramérica, "los criollos no encarnaron un papel dirigente en el logro de la independencia de Centroamérica"; por el contrario, fueron los indios y los mestizos quienes lucharon con tenacidad hasta colocar en una situación difícil a la Corona española. Conscientes de su incapacidad de mantener el dominio colonial, las autoridades reales pactaron con la aristocracia terrateniente y con los criollos acaudalados, pues temían "el éxito que pudieran alcanzar los sectores populares". A modo de conclusión, se afirma lo siguiente: "El acta de Independencia de 1821, es fruto del contubernio reaccionario entre terratenientes y funcionarios de la Corona, a espalda del movimiento popular que, con su intransigencia y su heroica lucha, la habian conquistado en la práctica."” 36

\section{La Independencia en los textos actuales (1990-2008)}

En los últimos quince años han salido a luz cuatro obras de síntesis sobre la historia de Nicaragua que actualmente se encuentran en uso en la educación secundaria, ya como textos u obras de referencia. Su marcada heterogeneidad obliga a examinarlos por separado, a fin de comprender su estructura y lógica explicativa antes de proceder a un análisis comparativo de sus diversos enfoques sobre el proceso independentista.

\subsubsection{Historia de Nicaragua, 1991}

La aparición de la Historia de Nicaragua del Dr. Germán J. Romero Vargas, en 1991, representó un notable avance con respecto a los textos de las décadas de 1970 y 1980 . La obra consta de dos tomos, con un total de 364 páginas incluyendo ejercicios para los alumnos, índice temático, glosario y apéndice documental. El autor privilegia el análisis de los aspectos demográficos, económicos, sociales y culturales en las distintas épocas de la historia de de 
Nicaragua, y tan sólo 5 de sus 33 capítulos se refieren a la vida política del país.

Congruente con este enfoque, Romero Vargas dedica tan sólo 5 páginas del último capítulo del Tomo I al tema de la independencia; es decir, poco menos del $2 \%$ de la parte expositiva del conjunto de su obra. En el Tomo II, aborda en 2 páginas las causas de las luchas sociales del siglo diecinueve, y dedica otras 7 a narrar los principales acontecimientos políticos y militares del período 1821-1854.

El capítulo dedicado a la emancipación colonial se halla dividido en cuatro subtemas, que se desarrollan desde un enfoque general a lo particular: "España y la evolución de la historia europea”, "La independencia de los países hispanoamericanos”, "La independencia de Guatemala” y “Nicaragua en 1821”.

Entre las causas de la ruptura colonial, Romero Vargas destaca la desventaja que significaba para el desarrollo de Hispanoamérica el hecho de depender de una metrópoli con una estructura económica estancada, de carácter agraria señorial, a la zaga de otras potencias mercantiles como Holanda, Inglaterra y Francia.

Además, enfatiza la significación universal de la Revolución Francesa que preparó las condiciones para la desintegración del imperio español, y reseña algunos acontecimientos trascendentales como la invasión napoleónica de 1808, y la creación de Juntas de Gobierno en varios lugares de América que marcaron "el principio de la separación definitiva”.

Sin embargo, dado el brevísimo espacio dedicado a este tema, el autor resume en unas pocas líneas las políticas coloniales desde las Reformas Borbónicas hasta la Constitución de Cádiz, lo que dificulta entender sus respectivos contextos y consecuencias, como se observa en la siguiente cita: “El gobierno español realizó algunas reformas en la segunda mitad del siglo dieciocho con el fin de modernizar su Imperio. En 1812 se decretó una Constitución que trataba de dar una respuesta positiva a las inquietudes expresadas por las clases dirigentes de las colonias. Todo fue en vano. La dependencia de las colonias americanas de España no era ventajosa para su desarrollo económico”.

A continuación, el autor regresa al año 1776 para referirse a la emancipación de las trece colonias británicas, y dedica un párrafo al surgimiento social de los criollos hispanoamericanos así como a sus motivos para impulsar la independencia. Brevemente, menciona los levantamientos de carácter social ocurridos en México, los del Virreinato de Santa Fe encabezados por el “aristócrata criollo” Simón Bolívar, y del Río de la Plata dirigidos por un “antiguo funcionario español”, José de San Martín. 
Al abordar el proceso independentista en el Reino de Guatemala, Romero Vargas parte del movimiento del 5 de noviembre de 1811 en San Salvador, pero enfatiza su carácter "puramente local” y asegura que éste fue dirigido por criollos que "en ningún momento" se proponían la separación de España: “antes bien, al contrario, todos juraron fidelidad al rey español Fernando Séptimo."

Agrega que en León, Nicaragua, también ocurrieron “algunos disturbios”, pues los "habitantes de los barrios de la ciudad anduvieron por las calles pidiendo: la creación de un nuevo gobierno, el nombramiento de nuevos jefes, la abolición del monopolio de la venta del aguardiente, la rebaja de los precios del tabaco y del papel sellado así como también la supresión de los impuestos de carne, carretas y ventas". A continuación, Romero Vargas dedica un par de líneas a las “agitaciones de carácter político” ocurridas en Masaya, Rivas y Granada, donde “los criollos que se habían levantado fueron condenados al destierro".

Finalmente, aborda en dos breves párrafos los acontecimientos de 1821, situando la independencia de México como antecedente inmediato de la emancipación centroamericana, aunque no menciona el Plan de Iguala ni explica la forma de gobierno adoptada por Iturbide. Al describir el desarrollo del cabildo abierto del 15 de septiembre, tan sólo se refiere a las discusiones en torno a la conveniencia de proclamar de inmediato la independencia o postergar esta decisión, identificando como protagonistas de este debate a José Cecilio del Valle y Pedro Molina.

Por tanto, su narrativa difiere de otros textos como el de Ayón, que sitúan a Pedro Molina en el exterior del Palacio Gubernamental acaudillando a una "inmensa multitud”, o como el de Gámez que atribuye una participación destacada al nicaragüense Miguel Larreinaga en el seno del cabildo abierto.

En las últimas tres páginas de este capítulo, Romero Vargas presenta un panorama socioeconómico de la Nicaragua de 1821, observando que las leyes y la estructura institucional españolas habían garantizado la supremacía de las principales familias de León y Granada pero, cuando este andamiaje jurídico perdió validez, afloraron las profundas tensiones ocultas bajo la aparente placidez de la sociedad colonial.

Si bien es cierto que "nunca nadie antes de 1821 puso en entredicho la autoridad real"concluye Romero - las quejas por los abusos de los poderosos en contra de los débiles, expresadas en centenares de pliegos enviados a las autoridades españolas, representan "el mejor testimonio de la permanencia de la lucha por la justicia y la libertad que impregnaba la mentalidad colectiva 
de todas las capas sociales de la provincia más allá de los crímenes, latrocinios y opresión que existieron". ${ }^{37}$

En el capítulo 3 del Tomo II, Romero Vargas retoma este enfoque, explicando que, al producirse la independencia, se desataron luchas por el poder entre las diferentes familias criollas de León y Granada. En este contexto "salieron a flote todas las tensiones que habian estado latentes en la sociedad colonial". La participación de un numeroso grupo de mestizos y mulatos en las contiendas imprimió a la lucha política un carácter social. ${ }^{38}$

En el año 2003, la editorial Hispamer publicó una versión resumida de la obra del Dr. Romero Vargas, en un formato más atractivo adaptado para estudiantes de primer año de secundaria. La narrativa sobre el proceso independentista se conservó igual, pero se suprimió el acápite sobre el panorama socioeconómico de la Nicaragua de $1821 .^{39}$

\subsubsection{Historia Básica de Nicaragua, 1993-1997.}

En la década de 1990, el Dr. Jorge Eduardo Arellano publicó los primeros dos volúmenes de una colección titulada Historia Básica de Nicaragua, utilizadas sobre todo como obras de referencia por la riqueza de datos y fuentes bibliográficas en que se sustentan.

En el primero, Arellano aborda el desarrollo del proceso independentista hasta 1816. Entre los factores exógenos que prepararon los ánimos insurreccionales contra el sistema colonial, destaca el espíritu del enciclopedismo difundido en Hispanoamérica gracias al movimiento reformador del Despotismo Ilustrado de los Borbones. Además, incluye el ejemplo de la independencia de los Estados Unidos, la invasión napoleónica y el ideario del constitucionalismo monárquico de las Cortes de Cádiz.

Arellano dedica 9 páginas del primer tomo a describir diversas rebeliones ocurridas en Centroamérica entre 1805 y 1813, como alzamientos indígenas, motines de artesanos y asonadas de la plebe, provocadas por abusos de las autoridades, la imposición de tributos, y los estancos del aguardiente y el tabaco. De acuerdo al autor, su interpretación del movimiento que surgió en León, Granada y Rivas entre 1811 y 1812 parte "desde una nueva perspectiva: gestados por la plebe, es decir populares y no, como se cree, promovido exclusivamente por el criollismo".

No obstante, también destaca la astucia del obispo García Jerez para controlar el movimiento en la capital de la provincia, la hegemonía de criollos independentistas en el caso de Granada, 
y la instrumentalización de la plebe en la villa de Rivas por parte de los mismos. Finalmente, se refiere a la Conjura de Belén del año 1813 como "el intento más serio de independencia en Centroamérica", pues fue gestado exclusivamente por elementos de extracción social media urbana con decididas ideas liberales, que perseguían llevar a cabo reformas sustanciales. Arellano concluye que todos estos movimientos insurreccionales influyeron en el proceso de la independencia al minar el poder y prestigio del gobierno español. ${ }^{40}$

El segundo volumen, con una extensión de 293 páginas, está dedicado al Siglo XIX. El tema de la emancipación colonial ocupa las 8 primeras páginas, y los acontecimientos políticomilitares del período 1822-1854 las 74 siguientes. En éste, Arellano ofrece un análisis, inspirado en la obra del historiador guatemalteco Severo Martínez Peláez, sobre los actores sociales y sus diversas actitudes ante la ruptura colonial.

En primer lugar, señala que los criollos habían conformado su posición de clase en el latifundio y en la explotación casi gratuita de la mano de obra indígena. Este carácter no sólo daba sentido y unidad a su grupo social, sino también explica su actitud reaccionaria: deseaban una forma de emancipación que les permitiera conservar la estructura colonial y gobernar de acuerdo a sus intereses económicos.

En contraste, la capa media alta urbana - integrada por el bajo clero, estudiantes, profesionales, militares de baja graduación, pequeños comerciantes, escribientes y oficinistas - tenía una actitud revolucionaria para su época: querían conquistar la independencia por la vía armada para reivindicar a la masa de trabajadores agrícolas, redistribuyéndoles la tierra.

Además, el autor reconoce la intervención de las “masas coloniales” en el proceso independentista, sobre todo en los eventos del 15 de septiembre de 1821 en la capital del Reino, precisando que se refiere a la plebe o clase pobre de mestizos citadinos. Sin embargo, aclara que su papel no fue hegemónico y que el sector mayoritario de las masas - la población indígena explotada demostró ser indiferente al mismo proceso que le era ajeno. Finalmente, los primeros lograron controlar el movimiento y, por tanto, la proclamación de la independencia fue el resultado del entendimiento de las dos clases dominantes de la colonia: la de los funcionarios españoles obligados por las circunstancias históricas - y la de los criollos.

En consecuencia, Arellano introduce una distinción entre "próceres oficiales” y “próceres verdaderos". Entre los primeros, sitúa al marqués de Aycinena, José Cecilio del Valle y el grupo de los trece firmantes del Acta de Independencia, cuya actitud era reaccionaria. En la lista de 
"próceres verdaderos" - intelectuales avanzados, capaces de concebir la independencia como un cambio - incluye al estudiante indígena Juan Modesto Hernández; religiosos como Benito Soto, Benito Miguelena, Víctor Castrillo y el "padre indio” Tomás Ruiz, todos de la provincia de Nicaragua, así como a varios dirigentes liberales guatemaltecos. ${ }^{41}$ Es notoria la ausencia del nicaragüense Miguel Larreinaga en ambas listas.

En cuanto a las causas de la inestabilidad política de Nicaragua en el período 1821-1857, Arellano otorga el primer lugar a la pugna entre dos centros regionales de poder económico: León y Granada. Sin embargo, resalta las contradicciones clasistas e ideológicas aclarando que, en el fondo, el choque no se daba propiamente entre granadinos y leoneses como tales, sino más bien entre granadinos propietarios, herederos de las estructuras coloniales que pretendían conservar aristocráticamente, y leoneses de extracción social media, muchas veces universitarios, identificados con la ideología liberal. La mayoría de los habitantes se veían coaccionados a respaldar una de estas tendencias rivales y engrosar sus fuerzas en los campos de batalla. ${ }^{42}$

\subsubsection{Historia de Nicaragua. Texto Básico. 2002}

El año 2002, la Universidad Nacional publicó una obra titulada Historia de Nicaragua, Texto Básico, cuya autoría recayó en cinco equipos integrados por catorce docentes e investigadores, en su mayoría miembros del Departamento de Historia de la UNAN-Managua. El tema de la independencia se aborda en un acápite titulado "Crisis de la estructura colonial y búsqueda de la autonomía administrativa en la provincia de Nicaragua. (1750-1821)”, cuya extensión representa alrededor del $2.5 \%$ del texto. ${ }^{43}$

Este manual constituye un caso singular, pues presenta un enfoque exclusivamente localista, omitiendo todos los argumentos clásicos sobre las causas y antecedentes de la independencia. Además, tiene como hilo conductor una interpretación sui generis sobre las Reformas Borbónicas y las consecuencias de la restauración de Fernando VII en el trono de Madrid.

De acuerdo a este texto, en el siglo XVIII el mercado capitalista, cada vez más pujante, demandaba cambios drásticos en los mecanismos económicos que se habían aplicado durante la Colonia, por lo que la Corona Española, bajo la familia Borbón, comprendió que era necesario introducir algunas modificaciones:

“Así fue necesario desmontar la política del monopolio comercial que se había aplicado 
sobre algunos productos sensibles de la economía colonial y se procedió a establecer el libre comercio para las colonias americanas, además de conceder la libertad de puertos, de manera que pudieran los territorios americanos comerciar con cualquier región del mundo que les permitiera mejores precios y productos". ${ }^{44}$

Prosiguen los autores afirmando que la libertad de puertos y de comercio llegó al Reino de Guatemala hacia el año 1790, pero los grandes mercaderes guatemaltecos no estaban dispuestos a hacerla extensiva a las demás provincias del istmo, y obstaculizaron las gestiones para que se declarara puerto libre a San Juan de Nicaragua. Los autores concluyen:

"A pesar que los nicaragüenses habian realizado diferentes gestiones para que se les autorizara el comercio por el río, la decisión guatemalteca les había sido adversa una y otra vez (...). Cuando las peticiones por la autonomía administrativa no tuvieron una respuesta favorable, se crearon las condiciones para los primeros levantamientos en la provincia."

Dichos alzamientos fueron dirigidos por algunos sectores de la oligarquía de la provincia, no con el interés de independizarse de España, sino de "establecer una autonomía respecto a Guatemala con el fin de poder ejercer sus propios derechos comerciales.” Además se afirma: "Algunas versiones indican que en la sublevación de Granada se decretó la libertad de comercio por el Río San Juan como un intento de romper con el monopolio guatemalteco".

A continuación, se lee lo siguiente: "En 1812, cuando el Rey Fernando VII fue restituido en su trono, revocó las decisiones relativas al libre comercio, con lo que sufrían en sus intereses no sólo los provincianos nicaragüenses, sino también, los comerciantes guatemaltecos por lo que empezaron a fraguar la Independencia".

En un tono muy parecido al del primer manual publicado por la UNAN en 1980, en el texto del año 2002 se afirma que la minoría dominante guatemalteca "generó un movimiento oportunista para anticiparse de esta manera a una posible ruptura del sistema que pudiesen llevar a cabo las minorías dominantes de las Provincias. La forma utilizada fue buscar como convencer a las autoridades de la Audiencia y a la Jerarquía Eclesiástica sobre la conveniencia de la independencia política de España, sin implicar modificaciones del status quo." 45

La interpretación del proceso independentista encontrada en el manual de la UNAN no concuerda con los estudios publicados en obras clásicas de referencia, como la Historia de América Latina de la Universidad de Cambridge, o la Historia General de Centroamérica de la Facultad Latinoamericana de Ciencias Sociales. 
En éstas, se lee que si bien los Borbones eliminaron muchas de las restricciones al intercambio entre la Península y las colonias, así como entre las distintas provincias hispanoamericanas, el comercio era "libre" únicamente a lo interno del imperio español; y no "con cualquier región del mundo que les permitiera mejores precios y productos", como se afirma en dicho manual. ${ }^{46}$

Por otra parte, la afirmación de que los comerciantes guatemaltecos impidieron que se autorizara el comercio por el Río San Juan, y que éste fue decretado por los criollos granadinos en 1812, se contradice con la obra de Tomás Ayón, quien reproduce una real cédula con fecha 26 de febrero de 1796, por medio de la cual el puerto de San Juan de Nicaragua fue habilitado "con la benéfica idea de que la Provincia de Nicaragua y otras del Reino de Guatemala, puedan hacer un comercio directo con la Metrópoli (...)”.

La guerra entre España e Inglaterra postergó la apertura de esta ruta hasta 1798, año en que Juan de Zavala llegó desde Sevilla a San Juan de Nicaragua con varias embarcaciones mercantes. ${ }^{47}$ El uso de esta ruta más bien se intensificó entre 1810 y 1811 pues, a raíz de la invasión napoleónica a España, el Consejo de Regencia se vio obligado a permitir el comercio directo entre Portobelo y la isla de Jamaica. Como resultado, en Nicaragua y Costa Rica se incentivó el comercio con Panamá, de donde se traían mercaderías de procedencia inglesa.

Si bien es cierto que existían complejas tensiones entre los comerciantes guatemaltecos, las autoridades coloniales y los provincianos, el argumento de que éstas prepararon las condiciones para los levantamientos de 1811-1812 es, cuando menos, controversial. ${ }^{48}$

La afirmación de que Fernando VII fue restituido al trono en 1812 y revocó la libertad de comercio también se contradice con todos los textos consultados, pues con el restablecimiento del absolutismo en 1814 no se abolió el Reglamento de Libre Comercio del año 1778, sino la Constitución Política de la Monarquía Española promulgada por las Cortes de Cádiz.

Aunque entre 1814 y 1817 Bustamante hostigó a los grandes comerciantes guatemaltecos vinculados a la familia Aycinena, el meollo del conflicto radicaba en la propuesta presentada por su diputado ante las Cortes de Cádiz de crear una Junta Central Superior en América Central, integrada por representantes de los cabildos del reino y dotada de considerables atribuciones que menoscababan la autoridad del Capitán General. ${ }^{49}$

Sin embargo, bajo la administración del sucesor de Bustamante, el pragmático Carlos de Urrutia, la familia Aycinena y sus allegados disfrutaron de mayores oportunidades de 
enriquecimiento, pues en 1819 no sólo se legalizó la importación de mercancías extranjeras vía la Habana, sino también el comercio con los ingleses establecidos en Belice, aunque bajo determinadas regulaciones y controles. ${ }^{50}$

Por tanto, el argumento de que la revocación de la libertad de comercio por parte de Fernando VII haya constituido el motivo por el cual los grandes comerciantes guatemaltecos fraguaron la independencia es, francamente, controversial. Esta decisión, tomada por la élite guatemalteca y las autoridades del Reino de Guatemala, el 15 de septiembre de 1821, no puede explicarse sin tomar en cuenta su contexto y antecedentes: la victoriosa campaña de Bolívar y San Martín, la rebelión de Riego y el restablecimiento de la Constitución de Cádiz, el Plan de Iguala y la independencia de México - temas ausentes en el manual publicado por la Universidad Nacional Autónoma de Nicaragua.

\subsubsection{Historia de Nicaragua, 2005-2008}

En el año 2005, el Instituto de Historia de Nicaragua y Centroamérica de la Universidad Centroamericana (IHNCA-UCA) publicó un libro de texto acompañado de un cuaderno de actividades de aprendizaje, cuya amplia acogida en centros de educación superior como media hizo necesaria una tercera edición en el 2008. ${ }^{51}$ Este manual dedica 17 páginas al tema de la independencia, y 24 al proceso de formación del Estado nacional durante el período 1821-1854; es decir, el 4.6\% y el 6.5\% de la extensión total del contenido expositivo, respectivamente.

El capítulo titulado "El Proceso Independentista" se halla organizado en cinco subtemas. En el primero se abordan los factores de índole económica, social, cultural y política que contribuyeron a socavar el Antiguo Régimen en Europa. Se destaca el rol de las nuevas formas de sociabilidad del siglo XVIII en el surgimiento de la idea de la sociedad contractual, concluyendo con una síntesis de los argumentos de los principales representantes del liberalismo político y económico.

Además, aborda un tema ausente en los demás manuales: el racismo del pensamiento antropológico de Buffon y sus discípulos, la reacción de la intelectualidad hispanoamericana, en particular, de los jesuitas criollos desterrados por Carlos III, y la influencia de sus escritos en el fortalecimiento de un sentido de identidad americana. ${ }^{52}$

El contexto internacional del proceso independentista ocupa el siguiente acápite, en el que se 
destacan la creación del primer Estado republicano en América del Norte, la Revolución Francesa, la organización de Juntas Provinciales que asumieron la soberanía a raíz de las abdicaciones de Bayona, y la desilusión de los diputados hispanoamericanos ante el rechazo, por parte de las Cortes de Cádiz, de sus demandas más sentidas: igualdad de representación, libre comercio, abolición de monopolios estatales, descentralización del poder, y ampliación de las funciones de sus Ayuntamientos.

El cuarto subtema consiste en una descripción de los principales acontecimientos políticos y militares del período 1810-1820: la insurrección popular encabezada por Hidalgo y Morelos, las sublevaciones ocurridas en Centroamérica en 1811-1812, la campaña de Bolívar y la rebelión de Riego. La narrativa sobre los levantamientos ocurridos en la provincia de Nicaragua ocupa alrededor del 50\% de la extensión de este acápite.

En el texto se deja abierta una interrogante sobre los motivos de los sublevados para jurar obediencia a Fernando VII y ofrecer al obispo de León la presidencia de la Junta de Gobierno, creada a raíz de la destitución del gobernador español. Al mismo tiempo, se hace relación a una carta secreta enviada por dicho obispo al capitán general en febrero de 1812, pidiéndole dos mil soldados para aplastar la sublevación. ${ }^{53}$ Sin embargo, se desaprovecha la oportunidad para profundizar en las contradicciones encontradas en las fuentes y hacer partícipe a los lectores del debate sobre el carácter de este movimiento.

En el último subtema, se destaca el rol de Pedro Molina, director de El Editor Constitucional, en la difusión de las ideas independentistas, la emancipación de México de acuerdo al Plan de Iguala, y los sucesos del 15 de septiembre de 1821. La narrativa de este último episodio recoge la versión de Gámez sobre el destacado protagonismo del intelectual nicaragüense Miguel Larreinaga.

El capítulo sexto, titulado "La Difícil Construcción de un Orden Nuevo”, parte de una explicaciónsobrelosproblemascomunesenfrentadosporlamayoríadelospuebloshispanoamericanos a la hora de organizar las nuevas instituciones republicanas. Entre éstos se destacan el militarismo y caudillismo, los conflictos entre liberales y conservadores y las rivalidades regionalistas.

En el siguiente acápite se analizan las características del sistema de gobierno adoptado por la República Federal de Centroamérica, así como las causas de su fracaso, explicando las ambigüedades de la Constitución Federal en cuanto a las atribuciones del Presidente federal y de los Jefes de Estado, sobre todo en materia fiscal, y los conflictos provocados por las reformas liberales en todo el istmo.

El último subtema centra la atención en los problemas particulares enfrentados por los 
nicaragüenses en el proceso de organización del Estado. Se recurre a la narrativa para describir cómo se manifestaron y "encarnaron" en Nicaragua los fenómenos del caudillismo, los conflictos ideológicos, las rivalidades regionales y las guerras de castas.

Además, se abordan los debates entre los principales intelectuales y líderes políticos de la época en torno a la definición de los términos del contrato social en la Constitución Política. Las deficiencias del sistema electoral se ejemplifican mediante una crónica de la época, para ilustrar por qué el ejercicio del voto no contribuía a resolver de manera pacífica las disputas por el poder, ni a garantizar la legitimidad de las autoridades. El capítulo concluye explicando las causas de la guerra civil de 1854 que abrió las puertas a la ocupación filibustera. ${ }^{54}$

\section{Historiografía e identidad nacional.}

A lo largo de este artículo hemos podido percibir cómo muchos libros de texto de Historia de Nicaragua contribuyeron a los esfuerzos del Estado por promover un sentido de identidad en torno al concepto del mestizaje, con miras a construir una nación racial y culturalmente homogénea. En la historiografía conservadora, el concepto de "identidad mestiza” se sustentaba en la premisa de la inferioridad de la cultura indígena con respecto a la hispánica, y en la oposición entre barbarie y civilización.

Otro componente básico del discurso de la Nicaragua mestiza, esgrimido en este caso por intelectuales e indigenistas liberales, era la idea de que los sobrevivientes de la Conquista habían sufrido un proceso de degradación a lo largo de la Colonia, como resultado de la segregación racial impuesta por las instituciones españolas y la opresiva explotación de los encomenderos.

El estereotipo del indígena como un ser degradado, objeto de lástima, era aplicado no sólo a los aborígenes de la época colonial, sino también a sus descendientes en el siglo XX. En el contexto de la transición hacia una economía agroexportadora, impulsada por gobernantes que aspiraban a modernizar el país según el modelo europeo, cobró fuerza la representación del indio como un obstáculo al progreso. Este discurso fue difundido, de manera persistente, en declaraciones y escritos oficiales, artículos periodísticos, libros de historia y manuales escolares desde el siglo XIX hasta bien entrado el siglo XX.

El elogio del mestizaje permitía justificar como una misión filantrópica las políticas estatales dirigidas a asimilar, dentro de los patrones culturales de la nueva nación mestiza, a los 
diversos grupos étnicos que aún vivían aferrados a su modo de vida "primitivo". En la práctica, los esfuerzos por "civilizar" a los indígenas se tradujeron en la conjugación de acciones coercitivas y consensuales para disolver las comunidades, privatizar sus tierras colectivas, disciplinar a los indígenas bajo nuevas formas de trabajo forzoso, y subordinar las identidades étnicas a una identidad nacional homogénea, hispano parlante y católica. ${ }^{55}$

La violencia no fue solamente física sino también simbólica. Ante la presión de este discurso dominante, muchos indígenas tendían a avergonzarse de sus distintivos étnicos. Entre 1880 y 1950, la mayoría de las comunidades nativas de las regiones del Pacífico y Centro del país se desintegraron, producto no sólo de disposiciones violentas, como el despojo de las tierras comunales y el trabajo forzoso, sino también de formas de violencia simbólica que fomentaron la alienación cultural.

En la década de 1980, los esfuerzos del gobierno por incorporar a las etnias de la Costa Atlántica a la nueva nación sandinista provocaron una resistencia masiva y violenta. Asumiendo este error, la Constitución Política promulgada en 1987 reconoció la naturaleza multiétnica del pueblo nicaragüense, así como derechos particulares a las comunidades de miskitos, creoles, mayangnas, garífunas y rama, incluyendo la libre expresión de sus culturas y la educación en lenguas maternas.

Por otra parte, los debates generados en torno a la conmemoración de quinto centenario del "descubrimiento de América", a inicios de la década de 1990, abrieron una coyuntura favorable que fue aprovechada por algunas comunidades indígenas del Pacífico de Nicaragua para reivindicar sus identidades étnicas y reclamar la devolución de sus tierras comunales. Esta iniciativa se vio estimulada por el apoyo de varios organismos internacionales e instituciones académicas. En consecuencia, el discurso asimilador, basado en la idealización de una identidad mestiza homogénea, poco a poco ha venido siendo desplazado por una valoración positiva de la diversidad cultural y étnica.

Este cambio de perspectiva se observa en la mayoría de los textos publicados a partir de 1990, en los que han desaparecido los estereotipos ofensivos basados en la oposición entre barbarie y civilización, así como también los epítetos peyorativos utilizados por historiadores como Gámez para referirse a los conquistadores o al clero católico.

Solamente Arellano se refiere de manera explícita a una identidad nicaragüense homogénea, arraigada en la cultura hispánica y el catolicismo. En efecto, al introducir el tema 
de la Conquista, este autor parte de unas reflexiones sobre la trascendencia universal de la efeméride del 12 de octubre de 1492. A su juicio, ésta significó la incorporación del Nuevo Mundo a la historia de la Europa occidental: una "sociedad pletóricamente vital que tenía, entre sus factores formativos, el clasicismo griego, la herencia jurídica de Roma y el cristianismo universalista". Por tanto, aunque reconoce que el descubrimiento tuvo resultados "desastrosos" para el continente americano, considera que lo derivado de la empresa colombina no puede ser totalmente abolido:

"En los años coloniales, aunque no se quiera, se encuentra un pasado definitorio; concretamente en Nicaragua, se dio una tradición de mestizaje que sustenta nuestra identidad cultural y raíces católicas. El orden colonial, aunque injusto en su estructura, fue un organismo viviente, abierto a todos los pobladores, sobre todo a los indios que-conducidos por los misioneros- asimilaron el cristianismo institucionalizado en la Iglesia. Esta estableció pueblos, centros educativos y de asistencia social; defendió los derechos de los indios contra los abusos de las autoridades rapaces y promovió el arte y el folklore, la difusión de la lengua que hablamos, de la religión en la que creemos y de los principios éticos que aún conservamos". ${ }^{56}$

Cabe aclarar que el libro de Arellano no presenta una visión peyorativa del mundo aborigen como en el caso de Ayón; por el contrario, sostiene que si bien las sociedades prehispánicas de Nicaragua nunca llegaron a los niveles de integración y desarrollo alcanzados por sus coetáneas de México y Perú, no deben ser minimizadas pues "constituyen el sustrato cultural más profundo de la cultura nicaragüense", ${ }^{57}$

No obstante, la cita anterior refleja la persistencia de una visión de la identidad nicaragüense como un producto homogéneo, sustentado en la tradición del mestizaje entre el mundo indígena y el español, caracterizado por dos componentes esenciales: la religión católica y la lengua castellana. Una presunta “identidad nacional” que, por omisión, excluye a las minorías étnicas de la Costa Atlántica de Nicaragua y a la creciente población no católica en todo el país, estimada por algunos especialistas entre el 27 y el 40 por ciento de los nicaragüenses. ${ }^{58}$

\section{Sugerencias de mejora}

La primera condición para mejorar el rigor científico y la calidad didáctica de los manuales nicaragüenses es promover la discusión y la crítica académica. Paradójicamente, el único texto 
que presenta serios errores de contenido en el tratamiento del tema de la independencia es de autoría colectiva.

En efecto, tal como se lee en la introducción al manual publicado por la Universidad Nacional Autónoma de Nicaragua, en la elaboración del mismo participaron 14 docentes de su Departamento de Historia y de otras universidades. Sin embargo, al parecer, cada autor escribió un fragmento del texto y no se llevó a cabo una puesta en común de los mismos para garantizar su validación ni la coherencia de la obra.

Otro aspecto preocupante es que, pese al reconocimiento general del carácter abierto e inconcluso del conocimiento histórico, la mayoría de los manuales contienen declaraciones que siguen reflejando una concepción cerrada y definitivista de la disciplina.

Por ejemplo, en la Guía del Alumno propuesta en un manual se insta a los estudiantes a desconfiar siempre de las afirmaciones tajantes y dogmáticas, pero en el texto expositivo se rechaza en términos absolutos cualquier posibilidad de que los movimientos de 1811-1812 pudieran haber tenido objetivos independentistas, usando expresiones como "puramente local", “en ningún momento”, “nunca nadie”, “todos”, etc.

Puesto que esa etapa del proceso independentista en Centroamérica sigue siendo un tema de debate entre los historiadores, convendría hacer partícipes a docentes y estudiantes de la discusión, dándoles a conocer la diversidad de interpretaciones existentes, y proponiendo el análisis de documentos en los que se encuentran versiones contrapuestas sobre estos acontecimientos.

El estudio de la accidentada historia de Nicaragua ha sido objeto de numerosas controversias, y éstas deberían aprovecharse para motivar a los alumnos a ejercitarse en el método del historiador, a reflexionar sobre el proceso de construcción del conocimiento, y a desarrollar su capacidad de pensamiento crítico. La participación de docentes y estudiantes en estos debates contribuiría al desarrollo de valores esenciales para la convivencia pacífica, tales como el respeto mutuo y la tolerancia frente a la diversidad de opiniones.

El tema de la independencia es muy propicio para ilustrar la multicausalidad de los procesos históricos, y para introducir una visión integradora en la enseñanza de la historia. Esta oportunidad no es aprovechada en todos los manuales; uno de ellos, incluso, enfoca la ruptura colonial desde una óptica estrecha y determinista, centrando la atención tan sólo en las contradicciones generadas por el monopolio comercial en el ámbito regional y local.

En contraste, otro manual ofrece una enriquecedora visión sobre las transformaciones 
culturales impulsadas por el movimiento reformador de los Borbones, que difundió el espíritu del enciclopedismo a través de las universidades iberoamericanas y diversas asociaciones científicas. La adopción de esta perspectiva integradora en todos los manuales estimularía el interés de los alumnos por conocer la historia no sólo de sus propios países, sino también la de los demás pueblos que constituyen la comunidad cultural iberoamericana.

En general, convendría dar mayor visibilidad en la narrativa histórica a las mujeres y los grupos sociales subalternos, identificando los intereses y reivindicaciones de distintos sectores étnicos y socioeconómicos en el proceso de construcción de los nuevos estados independientes.

Por otra parte, aunque en los prólogos de los manuales o en los objetivos de los programas se exprese que el propósito de estudiar el pasado es lograr una mejor comprensión del presente, urge un esfuerzo más efectivo por establecer esta relación en los textos y en las actividades propuestas para el alumnado.

Otro aspecto que todo manual debe contemplar es el aprovechamiento de recursos didácticos como mapas e imágenes, para ampliar el conocimiento histórico y desarrollar la capacidad analítica de los estudiantes. Solamente en uno de los textos nicaragüenses se aprecia un esfuerzo consistente en esta dirección, reflejado en la calidad de sus mapas, grabados y fotografías, así como en los ejercicios propuestos para adiestrar al alumnado a trabajar con este tipo de recursos.

Además, se debería cuidar que las actividades sugeridas en los manuales estimulen a los alumnos a reflexionar, argumentar y elaborar ideas propias, evitando preguntas simplistas que pueden responderse mediante la búsqueda de un fragmento del propio texto con fines memorísticos.

Finalmente, urge proporcionar a los docentes verdaderos programas orientados a la consecución de objetivos cognitivos, procedimentales y actitudinales, articulados entre sí de manera coherente desde una visión constructivista del proceso de enseñanza / aprendizaje. 


\section{CITAS Y NOTAS}

\section{(Endnotes)}

1 Zepeda, Hermenegildo, Diputado Presidente de la Asamblea Constituyente de 1858, “Discurso”, 15 de septiembre de 1858. Reproducido en: Revista Conservadora del Pensamiento Centroamericano, Vol. 15, No 72. Nicaragua: Editorial Alemana, septiembre 1966, pp. 6-7.

2 Esgueva, Antonio, Las Constituciones Políticas y sus reformas en la historia de Nicaragua, Managua: Editorial IHNCA-UCA, 2000, pp. 237 y 332.

3 Sobre la construcción de las identidades nacionales, véase: Hobsbawm, Eric, Naciones y Nacionalismo desde 1780, Barcelona, Editorial Crítica, 1991; Anderson, Benedict, Imagined Communities, London, Verso, 1991.

4 Molina Argüello, Carlos, La Enseñanza de la Historia en Nicaragua, México, Editorial Cultura, 1953, pp. 61-69.

5 Ayón, Tomás, Historia de Nicaragua, desde los tiempos más remotos hasta el año de 1852, Granada, Nicaragua, Tipografía “El Centroamericano”. El primer tomo fue publicado en 1882 y constaba de 428 páginas (17 x 28 cm.); el segundo tomo en 1887, con una extensión de 418 pp. (17 x 28 cm.), y el tercero en 1889, con 447 pp. ( 18 x 23 cm.).

6 Ayón, Tomás, Historia de Nicaragua, Tomo I, Managua: Fondo de Promoción Cultural BANIC, 1993; véase en especial las pp. 37, 44, 46, 50 y 51.

$7 \quad$ Ayón, (1993), Tomo I, pp. 54 - 56.

8 Ayón, (1993), Tomo I, p. 19.

9 Ayón, (1993), Tomo I, p. 18.

10 Ayón, (1993), Tomo I, p. 46.

11 Gámez, José Dolores, Historia de Nicaragua, desde los tiempos prehistóricos hasta 1860, en sus relaciones con España, México y Centro América, Managua, Tipografía de "El País”, 1889, 865 páginas (22.5 x 16 cm.).

12 Gámez, José Dolores, Historia de Nicaragua, 2a ed. Managua, Fondo de Promoción Cultual, BANIC, 1993, pp. 39 y 41.

13 Gámez, (1993), pp. 47, 74 y 99.

14 Gámez, (1993), pp. 204 y 205.

15 Esgueva Gómez, Antonio, Conflictos y Paz en la Historia de Nicaragua. Taller de Historia $N^{o}$ 7, Managua, IHNCA, 1999, p. 31.

16 Ayón, Tomás, Historia de Nicaragua, Managua: Fondo de Promoción Cultural BANIC, 1993, Tomo III, pp. 328-329; Gámez (1993), pp. 211-217.

17 Ayón (1993), Tomo III. Véase, en especial, las páginas 330, 332, 334, 337, 340, 348, 354, 359, 361 y 362.

18 Gámez, (1993), p. 214-222. 
20 Gámez, (1993), pp. 249 y 297.

21 Gámez, José Dolores, Catecismo de Historia Patria, 1889. (87 pp., 24 x 15 cm.); Catecismo Completo de Historia Patria para uso de las Escuelas Primarias, 1894, (190 pp. 24 x 15 cm.); Catecismo de Historia de Centroamérica para uso de las Escuelas Primarias, Managua, Tip. Nacional, 1900, 143 páginas; Compendio de Historia de Centro América, Managua, Compañía Tipográfica Internacional, s.f., (536 p. 13.5 x 19.5 cms.).

22 Gámez, María A, Compendio de Historia de Nicaragua, Managua, Tipografía Nacional, 1896, (96 pp. 12 x 18 cm.). Sobre la influencia de José Dolores Gámez en la historiografía didáctica nicaragüense, ver: Molina Argüello, Carlos, La enseñanza de la Historia en Nicaragua, México, I.P.G.H., 1953, p. 118.

23 Salvatierra, Sofonías, Compendio de Historia de Centro América, para los Institutos y Escuelas Normales, 1943, pp. 175-176, (329 pp., 14.5 x 22 cms.). En 1964 este manual fue reeditado por quinta vez.

24 Salvatierra, (1943), p. 38.

25 Quintana Orozco, Ofsman, Apuntes de Historia de Nicaragua, Octava edición, Managua, Fábrica Nacional de Textos Escolares (FANATEX), 1977, 282 pp. Compárese, por ejemplo, Gámez, (1993), pp. 204, 207, 217, 227 y 235, con Quintana (1977), pp. 107, 109, 111, 115 y 235.

26 Cabrales, Luis Alberto, Historia de Nicaragua. Curso Medio, Managua, Tip. Alemana de Carlos Heuberger, 1935, 112 pp. En 1940 alcanzó su cuarta edición, publicada en Granada, Escuela Tip. Salesiana, 100 pp. (122 x 14.7 cm.).

27 Cabrales, (1935), pp. 5, 12, 13 y 28.

28 Cabrales, (1935), pp. 51 y 52.

29 Cabrales, (1935), véase el Prólogo y la p. 59.

30 Cabrales, Luis Alberto, Historia Elemental de Nicaragua, , Managua, Editorial Recalde, 1951 (Octava Edición), 108 pp. (21 x 14.5 cm.).

31 Hermanos de las Escuelas Cristianas, Historia Universal de Centro América y Nicaragua, León, Editorial Hospicio, Colección La Salle, Decimosegunda edición, s.f., 170 pp. El ejemplar al que tuvimos acceso carece de fecha de publicación, pero abarca la historia de Nicaragua hasta el año 1964. Véanse, en especial, las pp. 117, 125 y 133.

32 Páiz Castillo, Ricardo, Historia de Nicaragua, León, Imprenta del Instituto Técnico “La Salle”, 6a edición, 1976, 206 pp. (14.5 x22 cm.). Véase, en especial, las pp. 67, 111, 118 y 125.

33 Universidad Nacional Autónoma de Nicaragua, (UNAN), Departamento de Ciencias Sociales, Sección de Historia, Apuntes de Historia de Nicaragua, (2 tomos), s.p.i., 1980. El tema de la independencia se aborda en las páginas 2 y 3 del primer tomo.

34 Esta visión teleológica de la historia es muy evidente en el documento titulado "El Significado Histórico del 19 de Julio”. Ver: UNAN, (1980), Tomo II, p. 422. 
35 Nicaragua, MED, “Programa de Historia Moderna y de América”, Séptimo Grado, Managua, 1987. En especial, véanse los objetivos generales 1, 2 y 4, en la página 5 del documento; así como los objetivos específicos 5, 7, 8 y 9. Como método didáctico, se sugiere "la exposición del material histórico concreto y la descripción emotiva de los acontecimientos históricos, a fin de lograr una mayor claridad política-ideológica”.

36 Ulloa Mayorga, et al, (1988), Apuntes de Historia de Nicaragua, León, Nicaragua: Editorial Universitaria, 1988, 234 páginas. Sobre este tema, véanse las pp. 11 y 12.

37 Romero V., Germán J., Red Editorial Iberoamericana, 1991, Tomo I, 156 pp.; Tomo II, 208 pp. (19 x 25 cms.). El tema de la independencia se aborda en el Tomo I, pp. 109-115.

38 Romero V., (1991), Tomo II, p. 37. El capítulo 4 contiene una apretada narrativa de 6 páginas sobre los principales acontecimientos políticos y militares del período 1821-1854.

39 Romero Vargas, Germán, Historia de Nicaragua, 1er año. Managua: HISPAMER, 2003, (1 $1^{\mathrm{a}}$ ed.) 152 p. ( 21 x 27 cms.).

40 Arellano, Jorge Eduardo, Historia Básica de Nicaragua. Vol. I. Managua, CIRA / Programa Textos Escolares Nacionales, $1^{\text {a }}$ ed. 1993, $2^{\text {a }}$ ed., 1997, 280 páginas. (13.5 x 21 cm.). Véase, en especial, el Tomo I, (1997) (2da ed.), p. 226 y siguientes.

41 Arellano, Jorge Eduardo. Historia Básica de Nicaragua. El Siglo XIX. (Vol. 2), Managua: CIRA, 1997, 292 páginas, (13.5 x 21 cm.). Véanse, en especial, las pp. 9 a 15. 42 Arellano, (1997), Vol. 2, pp. 54-55.

43 Romero Arrechavala, Jilma, et al. Historia de Nicaragua. Texto básico. Managua: Editorial Ciencias Sociales, INIES/UNAN, 2002. 435 pp. (17 cm. x 22.5 cm.). Aunque concebido para la educación superior, este texto ha sido incluido entre los textos aprobados por el Ministerio de Educación para su uso en la secundaria.

44 Romero Arrechavala, et al, (2002), p. 121. (El subrayado es nuestro).

45 Romero Arrechavala, et al, (2002), pp. 126-129.

$46 \quad$ Véase, por ejemplo: Lynch, John, “Los orígenes de la independencia hispanoamericana” y Anna, Timothy, “La independencia de México y América Central”, en Bethell, Leslie, ed., Historia de América Latina. Vol. 5. La Independencia. Barcelona, Editorial Crítica, 1991, en especial las páginas 12-18, y 62- 64. Sobre los objetivos particulares de las Reformas Borbónicas en Centroamérica, véase Solórzano Fonseca, Juan Carlos, “Los Años Finales de la Dominación Española (1750-1821), en: Historia General de Centroamérica, Tomo III, Madrid: Sociedad Estatal Quinto Centenario / Facultad Latinoamericana de Ciencias Sociales, 1993, pp. 48 y siguientes.

47 Sobre este tema, véase: Ayón, (1993), Tomo III, pp. 233- 234, 249, 278, 281-283, 314-315 y 320; Coronel Urtecho, José, “La Familia Zavala y la Política del Comercio en Centroamérica”, en: Revista del Pensamiento Centroamericano, Managua, Número Especial: 141 y 142, Junio y Julio, 1972, pp. 71- 83.

$48 \quad$ Véase, por ejemplo, Solórzano Fonseca, (1993), pp. 45-48 y 64-65; Floyd, Troy S., “Los comerciantes guatemaltecos, el gobierno y los provincianos, 1750-1800”, en: Cáceres, 
Luis René (ed.), Lecturas de Historia de Centroamérica, Costa Rica, BCIE, 1989, pp. 177197; y el documento "La diputación provincial de Nicaragua y Costa Rica pide a la regencia del reino la erección de una audiencia y capitanía general en estas dos provincias, con independencia de Guatemala. Año de 1814”, reproducido en la Revista de la Academia de Geografía e Historia de Nicaragua, Tomo VII, No III, Managua, noviembre de 1945, pp. 1-8. 49 Véase al respecto: García Laguardia, Jorge Mario, Orígenes de la Democracia Constitucional en Centroamérica, San José, EDUCA, 1976, (2ª ed.), pp. 312-328; Rodríguez, Mario, El experimento de Cádiz en Centroamérica, 1808-1826, México: Fondo de Cultura Económica, 1984; y Woodward, Ralph Lee, Jr., "Orígenes económicos y sociales de los partidos políticos guatemaltecos. (1773-1823)”, en: Cáceres, Luis René (ed.), Lecturas de Historia de Centroamérica, Costa Rica, BCIE, 1989, pp. 287 y siguientes; Pinto Soria, Julio César, “La Independencia y la Federación”, (1810-1840), en: Historia General de Centroamérica, Tomo III, (1993), p. 80.

50

Brignoli, Héctor, Historical Atlas of Central America, University of Oklahoma Press, 2003, pp. 166-167.

51 Kinloch Tijerino, Frances, Historia de Nicaragua, Managua: IHNCA-UCA, 2008, (3 edición), 406 páginas. (21.5 cm. x 27.5 cm.); Vijil Gurdián, Josefina, Haciendo Historia. Taller de Historia $N^{\circ}$ 9, Managua: IHNCA-UCA, 2006, 59 páginas.

52 Estos argumentos están basados sobre todo en las siguientes obras: Guerra, FrançoisXavier, Modernidad e Independencias: ensayos sobre las revoluciones hispánicas, México, Fondo de cultura Económica, 1993; Gerbi, Antonello, La Disputa del Nuevo Mundo. Historia de una polémica (1750-1900), México: Fondo de Cultura Económica, 1993; y Duchet, Michel, Antropología e Historia en el Siglo de las Luces. Buffon, Voltaire, Rousseau, Helvecio, Diderot, México: Siglo XXI, 1975.

53 La narrativa está basada en las fuentes compiladas por León Fernández bajo el título de Documentos relativos a los movimientos de independencia en el Reino de Guatemala, El Salvador: Ministerio de Instrucción Pública, 1929; y Textos fundamentales de la Independencia Centroamericana. Selección, Introducción y Notas de Carlos Meléndez, Costa Rica, Editorial Universitaria, 1971. En su carta, el obispo informa al Capitán General: “Desde el principio se pensó en una absoluta independencia y en formar una especie de república de toda la provincia".

$54 \quad$ Este capítulo está basado en: Kinloch Tijerino, Frances, Nicaragua: Identidad y Cultura Política (1821-1858), Managua: Banco Central de Nicaragua, 1999.

55 Un excelente análisis sobre este tema se encuentra en: “iVana Ilusión! Los indios de Matagalpa y el mito de la Nicaragua Mestiza (1880-1925)”, por el Dr. Jeffrey L. Gould, en: Nación y Etnia. ¿Identidad natural o creación cultural? Taller de Historia $N^{o}$ 6, Managua: IHN, 1994, pp. 61-90. Véase también: Dore, Elizabeth, Myths of Modernity. Peonage and Patriarchy in Nicaragua, Estados Unidos, Duke University Press, 2006. 
Indexaciones: Repositorio de Revistas UCR, DIALNET, Latindex, REDALYC Directorio y recolector de recursos digitales del Ministerio de Cultura de España, Directory of Open Access Journals. Diálogos Revista Electrónica de Historia ISSN 1409-469X. Número especial 2008. Dirección web: http://historia.fcs.ucr.ac.cr/dialogos.htm

$56 \quad$ Arellano, Jorge Eduardo. Historia Básica de Nicaragua, (Vol. 1). $2^{\text {a }}$ ed., (1997), p. 32.

$57 \quad$ Arellano, Jorge Eduardo. Historia Básica de Nicaragua, (Vol. 1). 2a ed., (1997), p. 29.

$58 \quad$ Cifras arrojadas en estudios realizados por el Dr. Manuel Ortega Hegg, director del

CASC-UCA. 